\title{
THE EFFECTS OF GOOGLE CLASSROOM IN LEARNING SYNTACTIC STRUCTURE
}

\section{Mungkap Mangapul Siahaan}

Universitas HKBP Nommensen Pematangsiantar Sumatera Utara, Indonesia

Email: mungkapsiahaan@gmail.com

\begin{abstract}
The purpose of this research is to respond to the bold learning at HKBP Nommensen University Pematang Siantar in the middle of compiling a strategic plan for implementing online education. At the same time, the misconceptions and myths of the difficulties of online teaching and learning, the technology available to support online support, the support and compensation required for high-quality instructors, and the needs of online students create challenges for such vision statements and planning documents. The method of this study is quantitative research and adapted Shaharance et.al (2016) questionnaire as the instrument to collect the data They are divided into four classes, two classes learn using Google Class and the other 2 learn without learning online. The research method used in this research is quantitative research and a questionnaire is used as data. The results showed that student achievement was higher after they studied Syntax Structure using Google Class.
\end{abstract}

Keywords: google classroom; online learning; teaching; learning snytactic structure

Coresponden Author

Email: mungkapsiahaan@gmail.com Article with open access under license

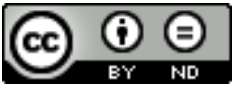

\section{Introduction}

The expansion of technology development in teaching learning activities has been rapidly increased in the circle of teaching learning activities. There are some researches have shown that many web-based collaborative activities facilitate the development of skills among college students: team work (Smith et al., 2006), social skills (Stoler et al., 2011), and basic computing skills (Bottge, Rueda, Kwon, Grant, \& LaRoque, 2009). Then the effectiveness of using online application has also been evaluated from diverse disciplines, information management (Rienzo \& Han, 2009).

The technology acceptance model (TAM) which was originally proposed by Davis in 1986 has inspired researchers to present chronological progress of TAM. All those researches change the field of education. Generally, during the late 1990s, new technologies were being invented and designed almost frequently in education. There are also theories of media uses are seen such as online applications, to enhance 
collaboration (Siahaan, Lumbangaol, et al., 2021). For example, researchers have found that in some classes use of a wiki (an essential component of Web 2.0) foster collaborative learning among students in a quick and flexible way (Tamis-LeMonda, Shannon, Cabrera, \& Lamb, 2004).

Among the newly developed online applications, Google classroom is an especially promising tool to exceed the need of teaching collaboration. Google classroom allows individuals to work on a common task without restrictions often imposed by traditional face-to-face contacts. Furthermore, Google classroom is accessible to the general public, regardless of location, as long as the internet is available (Rahmania Natasya, Sulistyani, \& Susanti, 2020)

Though these days online training or courses have become extremely popular, as more and more universities are offering online teaching methods however many universities consciously stay away from such online teaching methods, mostly due to misconception and limited financial resources. Over the years, our nation has changed the curriculum and many private schools are struggling to facilitate facilities to meet the need of accreditation. Therefore more budget are used to support conventional or traditional teaching methods (Siahaan, Haloho, Guk-guk, \& Panjaitan, 2021).

As the other universities facing the challenges and opportunities of the revolution industry era 4,0 the University of HKBP Nommensen Pematangsiantar starts to collaborate and implement technology in teaching process in order to create teachers graduation who are able to teach both with online and traditional teaching methods. Teaching is not more only about giving information or sharing knowledge of different subjects to the students but also an automatic collaborative system to produce innovation for the better life of people. Next, all the skill probably will exceed curriculum target.

Indonesian has thousands of islands, hundreds traditional languages and hundreds of tribes. The students of the university come from some islands. They come from different tribes and languages. When they graduate they will return to their each village. In each of their villages they do not have internet access therefore it is impossible to do online teaching. It is the other reason why traditional teaching methods are still used in the university (Bi \& Jiang, 2020)

In order to achieve the goals of online teaching methods, Google Classroom is implemented through the daily life of teaching methods. Google Classroom is a free web service in internet which is creating by Google Company for schools that aim to simplify distributing, creating and grading assignments in a paperless way. The goal of the Google Classroom service is to streamline the process of sharing teaching files or assignments between teachers and students. It is as a new approach to encounter the needs of creativity, simplicity and technology in teaching learning. Google Classroom combines Google drive for assignments creation and distribution such as Google Docs, Sheet and Slides for writing, Gmail for communication and Google Calendar for scheduling. Students can be invited to join a class through a private code, or automatically imported from a school domain. 
In the 2018 and 2019 academic year, the researcher has noticed the effects of Google Classroom in students learning. He has taught some different lessons in the teaching faculty by traditional method and the other classes by using Google Classroom. Teaching his lesson for some classes by using technology Google classroom may stimulate the students' eagerness and motivation to learn. It is looked from their scores that there is an impact of using Google classroom technology in teaching. He also admitted that curriculum and learning approach had been equally performed to all his classes. He taught his classes which having the same subjects with no different curriculum. There was also a responsibility and a sense of belonging controlled him doing his teaching. He was motivated on how to increase the eagerness and motivation of students to study. Therefore, he taught his classes of the same subject with different teaching method. And the emphasis of this research is laid on to find the differences between the class using of the Google Classroom and the traditional teaching method.

Syntactic structure is an obligation lesson for every student in English Language Education. It is studied at the second semester after every student has passed some introduction lessons. Syntactic structure by aiming to construct a grammar that can be viewed as a device of some sort for producing the sentences of the language under analysis. The analysis is where a man with a telescope is a constituent and one where is not. The work assumes a use theory of meaning, that grammars are embedded in a broader semiotic theory which uses the grammar to determine the meaning a reference of expressions. Syntactic structure is the part of grammar that governs the form of strings by which language users make statements, ask questions, give directives, and so on. The study of syntactic structure addresses the structure of sentences and their structural and functional relationships to one another. Here we use event-related potentials (ERPs) to show that native-like processing can also be observed in the largely under-researched domain of speech prosody - even when learners are exposed to their second language almost exclusively in a classroom setting. Participants listened to spoken sentences whose prosodic boundaries would either cooperate or conflict with the syntactic structure" (Nickels, Opitz, \& Steinhauer, 2013).

\section{Methods}

The method of this study is quantitative research and adapted Shaharance et.al (2016) questionnaire as the instrument to collect the data. All of the data were analyzed by using descriptive qualitative analysis in order to find a descriptive explanation. The result of this research finds that the students' interest to study the Syntactic Structure by using Google Classroom is bigger and satisfied. The population of the subject research was 136 students in English Language Education Department, University of HKBP Nommensen Pematangsiantar. They were divided into four classes, such as class Group A, class Group B, class Group C and class Group D. The research chose students of the classes because they already had experiences on using Google. Each of the class consisted of 34 students. 
In this chapter the researcher discusses the method of investigation which consists of subject of the research, object of the research, technique of collecting data, instrument of the research, and the steps in research design, the criterion of the assessments and data processing. To determine the effects of learning Syntactic Structure by using Google Classroom media, the researcher centralized his data to the 136 English students of the teaching faculty of the university. All of them were the students of 2018 academic year. They were divided into four classes, such as class Group A, class Group B, class Group C and class Group D. The research chose students of the classes because they already had experiences on using Google. Each of the class consisted of 34 students (Zhang, 2018). The researcher experiences teaching the lessons are very much influence this research. That is the reason how this research is made so the researcher can explore the function of Google Classroom in teaching activities. He seemed that the presence of Google Classroom is not only about collaborative teaching within technology or technology within teaching but also as a function of teaching.

\section{Result and Discusion}

\section{Analysis Data}

Related to the assessment of the students' achievement, the researcher used an evaluation. According to the Department of Education and culture (Depdikbud) evaluation can be defined as: .....is a series activity to gain, analyze and explain data about a process in teaching and learning done to systematic and continues that it becomes significant to take decision (No, 2013).

From the statement the researcher understood that evaluation is used to determine the achievement of teaching and learning process. To assess the student's achievement, the researcher uses the criterion evaluation issued by the Department of Education and Culture (Depdikbud, 1994) of Republic of Indonesia. Through the statement the researcher decided that a student achieves $65 \%$ of the score is qualified success.

\section{Analysis of the pre-test}

The total number of the students followed the pre-test were 100 students because every class had 25 students. The researcher gave 50 multiple choice questions to each of the student. Every student worked on the same questions and after they finished answering the questions the answer sheets as well as the pre-test paper were collected. The schedule of the pre-test was not taken at the same time but it was conducted at the first meeting.

Table 1

Result of the Pre-test Group A

\begin{tabular}{|c|c|c|c|}
\hline \multicolumn{2}{|c|}{ Group A } & & \\
\hline No. & Test Code & Score & $\mathbf{X}$ \\
\hline 1 & A-'1801030036 & 24,0 & 48,0 \\
\hline 2 & A-'1801030038 & 22,0 & 44,0 \\
\hline 3 & A-'1801030040 & 20,0 & 40,0 \\
\hline 4 & A-'1801030042 & 28,0 & 56,0 \\
\hline
\end{tabular}




\begin{tabular}{cccr}
\hline \multicolumn{4}{c}{ Group A } \\
\hline No. & Test Code & Score & X \\
\hline 5 & A-'1801030044 & 30,0 & 40,0 \\
\hline 6 & A-'1801030046 & 26,0 & 52,0 \\
\hline 7 & A-'1801030047 & 24,0 & 40,0 \\
\hline 8 & A-'1801030048 & 28,0 & 56,0 \\
\hline 9 & A-'1801030049 & 22,0 & 40,0 \\
\hline 10 & A-'1801030050 & 22,0 & 44,0 \\
\hline 11 & A-'1801030051 & 24,0 & 40,0 \\
\hline 12 & A-'1801030053 & 28,0 & 56,0 \\
\hline 13 & A-'1801030054 & 26,0 & 40,0 \\
\hline 14 & A-'1801030055 & 28,0 & 56,0 \\
\hline 15 & A-'1801030059 & 30,0 & 40,0 \\
\hline 16 & A-'1801030061 & 28,0 & 56,0 \\
\hline 17 & A-'1801030062 & 24,0 & 40,0 \\
\hline 18 & A-'1801030065 & 30,0 & 60,0 \\
\hline 19 & A-1801030067 & 30,0 & 40,0 \\
\hline 20 & A-1801030069 & 28,0 & 56,0 \\
\hline 21 & A-1801030070 & 30,0 & 40,0 \\
\hline 22 & A-1801030074 & 28,0 & 56,0 \\
\hline 23 & A-1801030075 & 28,0 & 40,0 \\
\hline 24 & A-1801030078 & 30,0 & 60,0 \\
\hline 25 & A-1801030081 & 28,0 & 40,0 \\
\hline & Total of the students $=25$ & 666,0 & $1.180,0$ \\
\hline & Mean & 26,6 & 47,2 \\
\hline
\end{tabular}

The average mark $=\frac{\Sigma \mathrm{X}}{\Sigma \mathrm{N}}$

$\mathrm{X}=$ Students' mark

$\mathrm{N}=$ Number of the students

The average achievement of the pre-test result $=\frac{\Sigma \mathrm{X}}{\Sigma \mathrm{N}}$

$$
\begin{aligned}
& =\frac{1180}{25} \\
& =47,2 \%
\end{aligned}
$$

Related to the criterion provided by Education and Culture of Republic of Indonesia (1994:34), learning process can be said success if a student achieves score $65 \%$ and above. The column shows that $47,2 \%$ students did not understand the material well. 
Table 2

Result of the Pre-test Group B

\begin{tabular}{cccc}
\hline \multicolumn{5}{c}{ Group B } & Score & X \\
\hline No. & Test Code & 20,0 & 40,0 \\
\hline 1 & A-1801030097 & 22,0 & 44,0 \\
\hline 2 & A-1801030098 & 26,0 & 52,0 \\
\hline 3 & A-1801030101 & 24,0 & 48,0 \\
\hline 4 & A-1801030102 & 22,0 & 44,0 \\
\hline 5 & A-1801030106 & 28,0 & 56,0 \\
\hline 6 & A-1801030107 & 30,0 & 60,0 \\
\hline 7 & A-1801030109 & 22,0 & 44,0 \\
\hline 8 & A-1801030110 & 28,0 & 56,0 \\
\hline 9 & A-1801030111 & 26,0 & 52,0 \\
\hline 10 & A-1801030112 & 24,0 & 48,0 \\
\hline 11 & A-1801030113 & 18,0 & 36,0 \\
\hline 12 & A-1801030114 & 22,0 & 44,0 \\
\hline 13 & A-1801030117 & 26,0 & 52,0 \\
\hline 14 & A-1801030119 & 28,0 & 56,0 \\
\hline 15 & A-1801030121 & 24,0 & 48,0 \\
\hline 16 & A-1801030122 & 22,0 & 44,0 \\
\hline 17 & A-1801030124 & 28,0 & 56,0 \\
\hline 18 & A-1801030126 & 30,0 & 60,0 \\
\hline 19 & A-1801030127 & 22,0 & 44,0 \\
\hline 20 & A-1801030129 & 26,0 & 52,0 \\
\hline 21 & A-1801030130 & 24,0 & 48,0 \\
\hline 22 & A-1801030133 & 22,0 & 44,0 \\
\hline 23 & A-1801030139 & 28,0 & 56,0 \\
\hline 24 & A-1801030140 & 30,0 & 60,0 \\
\hline 25 & A-1801030141 & 622,0 & $1.244,0$ \\
\hline & Total of the students = 25 & 49,8 \\
\hline & Mean &
\end{tabular}

The average mark $=\frac{\sum \mathrm{X}}{\Sigma \mathrm{N}}$

$\mathrm{X}=$ Students' mark

$\mathrm{N}=$ Number of the students

The average achievement of the pre-test result $=\frac{\Sigma X}{\Sigma N}$

$$
\begin{aligned}
& =\frac{1244}{25} \\
& =49,8 \%
\end{aligned}
$$

Related to the criterion provided by Education and Culture of Republic of Indonesia (1994:34), learning process can be said success if a student achieves score 
$65 \%$ and above. The column shows that $49,8 \%$ students did not understand the material well.

Table 3

Result of the Pre-test Group C

Group C

\begin{tabular}{|c|c|c|c|}
\hline No. & Test Code & Score & $\mathbf{X}$ \\
\hline 1 & A-1801030094 & 30,0 & 60,0 \\
\hline 2 & A-1801030099 & 22,0 & 44,0 \\
\hline 3 & A-1801030100 & 26,0 & 52,0 \\
\hline 4 & A-1801030115 & 24,0 & 48,0 \\
\hline 5 & A-1801030116 & 20,0 & 40,0 \\
\hline 6 & A-1801030120 & 22,0 & 44,0 \\
\hline 7 & A-1801030125 & 22,0 & 44,0 \\
\hline 8 & A-1801030131 & 28,0 & 56,0 \\
\hline 9 & A-1801030136 & 26,0 & 52,0 \\
\hline 10 & A-1801030143 & 22,0 & 44,0 \\
\hline 11 & A-1801030144 & 24,0 & 48,0 \\
\hline 12 & A-1801030149 & 26,0 & 52,0 \\
\hline 13 & A-1801030152 & 22,0 & 44,0 \\
\hline 14 & A-1801030156 & 28,0 & 56,0 \\
\hline 15 & A-1801030157 & 28,0 & 56,0 \\
\hline 16 & A-1801030163 & 30,0 & 60,0 \\
\hline 17 & A-1801030167 & 30,0 & 60,0 \\
\hline 18 & A-'1801030045 & 22,0 & 44,0 \\
\hline 19 & A-'1801030052 & 28,0 & 56,0 \\
\hline 20 & A-'1801030056 & 28,0 & 56,0 \\
\hline 21 & A-'1801030064 & 26,0 & 52,0 \\
\hline 22 & A-1801030068 & 24,0 & 48,0 \\
\hline 23 & A-1801030071 & 24,0 & 48,0 \\
\hline 24 & A-1801030072 & 26,0 & 52,0 \\
\hline 25 & A-1801030073 & 26,0 & 52,0 \\
\hline \multicolumn{2}{|c|}{ Total of the students $=25$} & \multicolumn{2}{|r|}{$634,0 \quad 268,0$} \\
\hline & Mean & & $25,4 \quad 50,7$ \\
\hline
\end{tabular}

The average mark $=\frac{\Sigma \mathrm{X}}{\Sigma \mathrm{N}}$

$\mathrm{X}=$ Students' mark

$\mathrm{N}=$ Number of the students

The average achievement of the pre-test result $=\frac{\Sigma X}{\Sigma N}$

$=\frac{1268}{25}$
$=50,7 \%$


Related to the criterion provided by Education and Culture of Republic of Indonesia (1994:34), learning process can be said success if a student achieves score $65 \%$ and above. The column shows that $50,7 \%$ students did not understand the material yet.

\section{Table 4}

Result of the Pre-test Group D

\begin{tabular}{|c|c|c|c|}
\hline \multicolumn{3}{|c|}{ Group D } & \multirow[b]{2}{*}{$\mathbf{X}$} \\
\hline No. & Test Code & Score & \\
\hline 1 & A-1801030087 & 24,0 & 48,0 \\
\hline 2 & A-1801030088 & 24,0 & 48,0 \\
\hline 3 & A-1801030091 & 26,0 & 52,0 \\
\hline 4 & A-1801030095 & 28,0 & 56,0 \\
\hline 5 & A-1801030096 & 26,0 & 52,0 \\
\hline 6 & A-1801030103 & 24,0 & 48,0 \\
\hline 7 & A-1801030104 & 22,0 & 44,0 \\
\hline 8 & A-1801030105 & 30,0 & 60,0 \\
\hline 9 & A-1801030108 & 28,0 & 56,0 \\
\hline 10 & A-1801030118 & 28,0 & 56,0 \\
\hline 11 & A-1801030123 & 22,0 & 44,0 \\
\hline 12 & A-1801030128 & 24,0 & 48,0 \\
\hline 13 & A-1801030132 & 24,0 & 48,0 \\
\hline 14 & A-1801030134 & 22,0 & 44,0 \\
\hline 15 & A-1801030135 & 20,0 & 40,0 \\
\hline 16 & A-1801030137 & 20,0 & 40,0 \\
\hline 17 & A-1801030138 & 30,0 & 60,00 \\
\hline 18 & A-1801030142 & 28,0 & 56,0 \\
\hline 19 & A-1801030145 & 28,0 & 56,0 \\
\hline 20 & A-1801030147 & 30,0 & 60,0 \\
\hline 21 & A-1801030148 & 26,0 & 52,0 \\
\hline 22 & A-1801030151 & 24,0 & 48,0 \\
\hline 23 & A-1801030154 & 24,0 & 48,0 \\
\hline 24 & A-1801030155 & 22,0 & 44,0 \\
\hline 25 & A-1801030158 & 22,0 & 44,0 \\
\hline & Total of the students $=25$ & & 252,0 \\
\hline & Mean & & 50,1 \\
\hline
\end{tabular}

$$
\Sigma X
$$

The average mark $=\overline{\Sigma \mathrm{N}}$

$$
\Sigma \mathrm{N}
$$

$\mathrm{X}=$ Students' mark

$\mathrm{N}=$ Number of the students

The average achievement of the pre-test result $=\frac{\sum \mathrm{X}}{\Sigma \mathrm{N}}$ 


$$
\begin{aligned}
& =\frac{1252}{25} \\
& =50,1 \%
\end{aligned}
$$

Related to the criterion provided by Education and Culture of Republic of Indonesia (1994:34), learning process can be said success if a student achieves score $65 \%$ and above. The column shows that $50,1 \%$ students did not understand the material.

\section{The analysis of the posttest}

The sixth meeting was the last session for the lesson to every class. The researcher conducted the post-test to class or group A on January 22, 2019, B on January 23, 2019, C on January 25, 2019 and D on January 24, 2019. The questions on the post-test were the same with the questions on the pre-test. There were totally 50 questions for the post-test.

Tabel 5

The analysis of post-test Group A

Group A 
$\Sigma$ score

The average mark $=$

$$
\Sigma \mathrm{N}
$$

Score $=$ Students' score

$\mathrm{N}=$ Number of the student

$\begin{aligned} \text { The average achievement of the pre-test result } & =\frac{\Sigma \text { Score }}{\Sigma \mathrm{N}} \\ & =\frac{2084}{25} \\ & =83,3 \%\end{aligned}$

Related to the criterion provided by Education and Culture of Republic of Indonesia (1994:34), learning process can be said success if a student achieves score $65 \%$ and above. The column shows that $83,3 \%$ students having scores more than 65 .

Tabel 6

The analysis of post-test Group B

\begin{tabular}{|c|c|c|c|}
\hline & Group B & & \\
\hline No. & Test Code & $\mathbf{X}$ & Score \\
\hline 1 & A-1801030097 & 42 & 84 \\
\hline 2 & A-1801030098 & 41 & 82 \\
\hline 3 & A-1801030101 & 39 & 78 \\
\hline 4 & A-1801030102 & 44 & 88 \\
\hline 5 & A-1801030106 & 44 & 88 \\
\hline 6 & A-1801030107 & 39 & 78 \\
\hline 7 & A-1801030109 & 45 & 90 \\
\hline 8 & A-1801030110 & 40 & 80 \\
\hline 9 & A-1801030111 & 39 & 78 \\
\hline 10 & A-1801030112 & 40 & 80 \\
\hline 11 & A-1801030113 & 40 & 80 \\
\hline 12 & A-1801030114 & 43 & 86 \\
\hline 13 & A-1801030117 & 44 & 88 \\
\hline 14 & A-1801030119 & 45 & 90 \\
\hline 15 & A-1801030121 & 40 & 80 \\
\hline 16 & A-1801030122 & 44 & 88 \\
\hline 17 & A-1801030124 & 43 & 86 \\
\hline 18 & A-1801030126 & 44 & 88 \\
\hline 19 & A-1801030127 & 42 & 84 \\
\hline 20 & A-1801030129 & 41 & 82 \\
\hline 21 & A-1801030130 & 39 & 78 \\
\hline 22 & A-1801030133 & 39 & 78 \\
\hline 23 & A-1801030139 & 40 & 80 \\
\hline 24 & A-1801030140 & 42 & 84 \\
\hline 25 & A-1801030141 & 40 & 80 \\
\hline
\end{tabular}




\begin{tabular}{crr}
\hline otal of the students $=25$ & 1.039 & 2.078 \\
\hline Mean & 42 & 83 \\
\hline$\Sigma$ score & &
\end{tabular}

The average mark $=$

$$
\Sigma \mathrm{N}
$$

Score $=$ Students' score

$\mathrm{N}=$ Number of the students

$\Sigma$ Score

The average achievement of the pre-test result $=$

$$
\begin{aligned}
& \begin{array}{l}
\Sigma \mathrm{N} \\
2078
\end{array} \\
\hline & \frac{25}{83,0 \%}
\end{aligned}
$$

According to the criterion provided by Education and Culture of Republic of

\begin{tabular}{|c|c|c|c|}
\hline \multicolumn{3}{|c|}{ Group C } & \multirow[b]{2}{*}{ Score } \\
\hline No. & Test Code & $\mathbf{X}$ & \\
\hline 1 & A-1801030094 & 43 & 86 \\
\hline 2 & A-1801030099 & 40 & 80 \\
\hline 3 & A-1801030100 & 44 & 88 \\
\hline 4 & A-1801030115 & 42 & 84 \\
\hline 5 & A-1801030116 & 41 & 82 \\
\hline 6 & A-1801030120 & 39 & 78 \\
\hline 7 & A-1801030125 & 39 & 78 \\
\hline 8 & A-1801030131 & 40 & 80 \\
\hline 9 & A-1801030136 & 43 & 86 \\
\hline 10 & A-1801030143 & 43 & 86 \\
\hline 11 & A-1801030144 & 43 & 86 \\
\hline 12 & A-1801030149 & 43 & 86 \\
\hline 13 & A-1801030152 & 43 & 86 \\
\hline 14 & A-1801030156 & 40 & 80 \\
\hline 15 & A-1801030157 & 40 & 80 \\
\hline 16 & A-1801030163 & 45 & 90 \\
\hline 17 & A-1801030167 & 45 & 90 \\
\hline 18 & A-'1801030045 & 44 & 88 \\
\hline 19 & A-'1801030052 & 44 & 88 \\
\hline 20 & A-'1801030056 & 43 & 86 \\
\hline 21 & A-'1801030064 & 39 & 78 \\
\hline 22 & A-1801030068 & 38 & 76 \\
\hline 23 & A-1801030071 & 38 & 76 \\
\hline 24 & A-1801030072 & 38 & 76 \\
\hline
\end{tabular}
Indonesia (1994:34), learning process can be said success if a student achieves score $65 \%$ and above. The column shows that $83,0 \%$ students having scores more than 65 .

Tabel 7

The analysis of post-test Group C 


\begin{tabular}{rrrr}
$25 \quad$ A-1801030073 & 40 & 80 \\
\hline Total of the students $=25$ & 1.037 & 2.074 \\
\hline Mean & 41 & 83 \\
\hline
\end{tabular}

The average mark $=\frac{\Sigma \text { score }}{\Sigma \mathrm{N}}$

Score $=$ Students' score

$\mathrm{N}=$ Number of the students

The average achievement of the pre-test result $=\frac{\Sigma \text { Score }}{\Sigma \mathrm{N}}$

$$
\begin{aligned}
& =\frac{2074}{25} \\
& =83,0 \%
\end{aligned}
$$

According to the criterion provided by Education and Culture of Republic of Indonesia (1994:34), learning process can be said success if a student achieves score $65 \%$ and above. The column shows that $83,0 \%$ students having scores more than 65 .

Tabel 8

The analysis of post-test Group D

\begin{tabular}{clrr}
\hline No. & Test Code & X & Score \\
\hline 1 & A-1801030087 & 43 & 86 \\
\hline 2 & A-1801030088 & 44 & 88 \\
\hline 3 & A-1801030091 & 43 & 86 \\
\hline 4 & A-1801030095 & 40 & 80 \\
\hline 5 & A-1801030096 & 40 & 80 \\
\hline 6 & A-1801030103 & 40 & 80 \\
\hline 7 & A-1801030104 & 41 & 82 \\
\hline 8 & A-1801030105 & 41 & 82 \\
\hline 9 & A-1801030108 & 41 & 82 \\
\hline 10 & A-1801030118 & 41 & 82 \\
\hline 11 & A-1801030123 & 42 & 84 \\
\hline 12 & A-1801030128 & 42 & 84 \\
\hline 13 & A-1801030132 & 41 & 82 \\
\hline 14 & A-1801030134 & 41 & 82 \\
\hline 15 & A-1801030135 & 40 & 80 \\
\hline 16 & A-1801030137 & 40 & 80 \\
\hline 17 & A-1801030138 & 39 & 78 \\
\hline 18 & A-1801030142 & 38 & 76 \\
\hline 19 & A-1801030145 & 38 & 76 \\
\hline 20 & A-1801030147 & 39 & 78 \\
\hline 21 & A-1801030148 & 39 & 78 \\
\hline 22 & A-1801030151 & 39 & 78 \\
\hline & & &
\end{tabular}




\begin{tabular}{cccc}
23 & A-1801030154 & 40 & 80 \\
\hline 24 & A-1801030155 & 45 & 90 \\
\hline 25 & A-1801030158 & 44 & 88 \\
\hline Total of the students $=25$ & 1.021 & 2.042 \\
\hline \multicolumn{2}{r}{ Mean } & 41 & 82 \\
\hline
\end{tabular}

The average mark $=\frac{\Sigma \text { score }}{\Sigma \mathrm{N}}$

Score $=$ Students' score

$\mathrm{N}=$ Number of the students

The average achievement of the pre-test result $=\frac{\Sigma \text { Score }}{\Sigma \mathrm{N}}$

$$
\begin{aligned}
& =\frac{2042}{25} \\
& =82,0 \%
\end{aligned}
$$

According to the criterion provided by Education and Culture of Republic of Indonesia (1994:34), learning process can be said success if a student achieves score $65 \%$ and above. The column shows that $82,0 \%$ students having scores more than 65 .

\section{The analysis of the field notes}

There were some strong information influenced the data of the researcher that were shown by the students. These feedback were very dominate to support the data of the researcher that the students were very interesting studying Syntactic Structure by using media Google Classroom. These are the specific results of the analysis of the field notes, as:

1. The performances of the students during the lessons

Access to Google Classroom needs laptop or smart phone and internet connection. During the lessons, the researcher chose a class facilitated with a wifi and everyone had access to the internet. Related to the data, there were 25 students chose for every class and all of them were very enthusiastic for the lessons. All of them were very cooperative working in teams to finish their team discussion. They also could connect their works with other app and webs to their Google Classroom. Through the class notes for every lesson, everyone gave their responses, such as giving questions, answering questions and doing assignment before the final date. There was no absence recorded.

2. The result out of the box

There were 34 students for each of the class for every meeting. There was no one absent or coming late. Everyone was joining the group presentation because there were some presentation doing using Google Classroom and every student was actively participated. It was proved through their commentaries left on the class work stream. 
Through the analysis, the researcher concluded that everyone in the class was very interesting studying Syntactic Structure.

\section{Analysis of questionnaire}

The analysis of questionnaire was started differently for every class. Questionnaire for group or class A was conducted on January 22, 2019, group B on January 23, 2019, group C on January 25, 2019 and group D on January 24, 2019. Every class had 25 respondents. The researcher gave 5 questions to be answered. The students asked to answer with "yes" or "no."

Question for number 1 was about the students' opinion whether the students were interested to learn Syntactic Structure by using Google Classroom or not. There were $100 \%$ students answering "yes" that they were interesting studying Syntactic Structure by using Google Classroom.

Question number 2 was about whether the Google Classroom helped the students to learn Syntactic Structure or not. There were $100 \%$ students answering "yes" that Google Classroom helped them to learn Syntactic Structure.

Question number 3 was about whether there was an increasing achievement in learning Syntactic Structure or not. There were $100 \%$ students answering "yes" that they felt and saw their achievement in learning Syntactic Structure.

Questions number 4 was about whether there was an influence of Google Classroom in learning Syntactic Structure or not. There were $100 \%$ students answering "yes" that they realized the influence of Google Classroom in learning Syntactic Structure.

Questions number 5 was about the students' opinion whether Google Classroom application should be given continuously or not. There were $100 \%$ students answering "yes" that they expected the teaching learning to be given by using Google Classroom.

\section{Findings}

Every student responded on the use of Google Classroom. Totally there were 4 classes and each of the class had 25 students. All of the students in the classes had completed answering the pre-test, assignments, post-test and the questionnaire. In class A there were 2 male and 23 female, in class B there were 3 male and 22 female, in class $C$ there were 25 female and in class D there were 6 male and 19 female. There were 100 students totally participated in the research. Through the result of the data analysis, the researcher concluded recommendation for further research, as:

1. The students' achievements in studying Syntactic Structure were increasing and improving. It is proved by the comparative result between the pre-test and the post-test for every class. Class A pre-test is $47,2 \%$ and the post-test is $83,3 \%$; Class B pre-test is $49,8 \%$ and the post-test is $83,0 \%$; Class C pre-test is $50,7 \%$ and the post-test is $83,0 \%$ and Class D pre-test is $50,1 \%$ and the post-test is $82,0 \%$.

2. Based on the questionnaire results, all of the students declared that studying Syntactic Structure by using Google Classroom helped them in mastering the 
lesson. Moreover, Google Classroom could increase the students' motivation to learn Syntactic Structure.

3. Google Classroom was the window of the knowledge because every student had a huge access to explore everything about Syntactic Structure from other books, web and library.

4. Every student expected that teaching-learning activities should use Google Classroom as media because it was easy and comfortable for everyone.

5. Class A first assignment was 72,28\%; second assignment was 77,64\% and third assignment was $79,80 \%$. Class B first assignment was 68,44\%; second assignment was $76,77 \%$ and third assignment was $78,64 \%$. Class $\mathrm{C}$ first assignment was $68,20 \%$; second assignment was $71,92 \%$ and third assignment was $74,52 \%$. Class D first assignment was 69,28\%; second assignment was $69,92 \%$ and the third assignment was $75,80 \%$. Through the series of all the assignment results, both the students and teachers sides felt satisfy with the achievement. These show that Google Classroom is useful and helpful.

\section{Discussion}

According to the criterion provided by Education and Culture of Republic of Indonesia (1994:34), learning process can be said success if a student achieves score $65 \%$ and above. From the findings it is concluded that every student in group class $\mathrm{A}, \mathrm{B}, \mathrm{C}$ and $\mathrm{D}$ have passed the standard score. The findings prove that teaching Syntactic Structure by using Google Classroom has improved students' achievement.

\section{Conclusion}

Chapter IV has proved that students achievement were higher after they studied Syntactic Structure by using Google Classroom. Students were very interesting to learn Syntactic Structure and they were actively showed their interest through their activities in the class as well as their assignment scores. Google Classroom has successfully helped the students to understand and master the lesson. It is proved that both teacher and students are totally useful to success teaching activities. 


\section{BIBLIOGRAFI}

Bi, Peng, \& Jiang, Jingyang. (2020). Syntactic complexity in assessing young adolescent EFL learners' writings: Syntactic elaboration and diversity. System, 91, 102248.

Bottge, Brian A., Rueda, Enrique, Kwon, Jung Min, Grant, Timothy, \& LaRoque, Perry. (2009). Assessing and tracking students' problem solving performances in anchored learning environments. Educational Technology Research and Development, 57(4), 529-552.

Brown, H. Douglas. (2007). Principles of language learning and teaching fifth edition. White Plains, NY: Pearson Education.

Mehra, Mandeep R., Kobashigawa, Jon, Starling, Randall, Russell, Stuart, Uber, Patricia A., Parameshwar, Jayan, Mohacsi, Paul, Augustine, Sharon, Aaronson, Keith, \& Barr, Mark. (2006). Listing criteria for heart transplantation: International Society for Heart and Lung Transplantation guidelines for the care of cardiac transplant candidates-2006. The Journal of Heart and Lung Transplantation, 25(9), 1024-1042.

Nickels, Stefanie, Opitz, Bertram, \& Steinhauer, Karsten. (2013). ERPs show that classroom-instructed late second language learners rely on the same prosodic cues in syntactic parsing as native speakers. Neuroscience Letters, 557, 107-111.

No, Permendikbud. (2013). th 2013 tentang standar proses pada kurikulum 2013. Depdikbud RI.

Rahmania Natasya, Putri, Sulistyani, Sulistyani, \& Susanti, Yunik. (2020). The Implementation Of Google Classroom To Teach Productive Skills In New Normal Era. Journal of English Teaching and Research, 1-6.

Rienzo, Thomas, \& Han, Bernard. (2009). Teaching Tip: Microsoft or Google Web 2.0 Tools for Course Management. Journal of Information Systems Education, 20(2), 123.

Siahaan, Kevin William Andri, Haloho, Uci Nursanty, Guk-guk, Maria Paulina Angle Raja, \& Panjaitan, Fitri Riana. (2021). Implementation of Discovery Learning Methods to Improve Science Skills in Kindergarten B Children. Jurnal Pendidikan Edutama, 8(1), 33-40.

Siahaan, Kevin William Andri, Lumbangaol, Sudirman T. P., Marbun, Juliaster, Nainggolan, Ara Doni, Ritonga, Jatodung Muslim, \& Barus, David Patria. (2021). Pengaruh Model Pembelajaran Inkuiri Terbimbing dengan Multi Representasi terhadap Keterampilan Proses Sains dan Penguasaan Konsep IPA. Jurnal Basicedu, 5(1), 195-205.

Smith, Sidney C., Allen, Jerilyn, Blair, Steven N., Bonow, Robert O., Brass, Lawrence 
M., Fonarow, Gregg C., Grundy, Scott M., Hiratzka, Loren, Jones, Daniel, \& Krumholz, Harlan M. (2006). AHA/ACC guidelines for secondary prevention for patients with coronary and other atherosclerotic vascular disease: 2006 update: endorsed by the National Heart, Lung, and Blood Institute. Journal of the American College of Cardiology, 47(10), 2130-2139.

Standage, Martyn, \& Treasure, Darren C. (2002). Relationship among achievement goal orientations and multidimensional situational motivation in physical education. British Journal of Educational Psychology, 72(1), 87-103.

Stoler, Mark H., Wright Jr, Thomas C., Sharma, Abha, Apple, Raymond, Gutekunst, Karen, \& Wright, Teresa L. (2011). High-risk human papillomavirus testing in women with ASC-US cytology: results from the ATHENA HPV study. American Journal of Clinical Pathology, 135(3), 468-475.

Tamis-LeMonda, Catherine S., Shannon, Jacqueline D., Cabrera, Natasha J., \& Lamb, Michael E. (2004). Fathers and mothers at play with their 2-and 3-year-olds: Contributions to language and cognitive development. Child Development, 75(6), 1806-1820.

Zhang, Meixiu. (2018). Collaborative writing in the EFL classroom: The effects of L1 and L2 use. System, 76, 1-12. 